\title{
Interactive comment on "Soil salinization risk assessment owing to poor water quality drip irrigation: A case study from an olive plantation at the arid to semi-arid Beit She'an Valley, Israel" by Vladimir Mirlas et al.
}

Vladimir Mirlas et al.

kobia@ariel.ac.il

Received and published: 14 November 2020

Thank you for the comment, if you have additional questions or suggestions please do not hesitate to share them.

Kobi 